\title{
Multiple Versions of Breuddwyd Pawl as a Source to Study the Work of Welsh Translators
}

\author{
Elena Parina
}

\section{Introduction}

Although the image of Middle Welsh prose is dominated both in academia and outside of it by the Four Branches of the Mabinogi and Culhwch ac Olwen, translations constitute the majority of text witnesses that have come down to us. ${ }^{1}$ The proportion of translated vs. native texts in medieval manuscripts cannot be ascribed to the vagaries of manuscript preservation but clearly manifests the importance of translations for Welsh readers. Whereas we find the Four Branches in their entirety in only two manuscripts, the translations of different versions of Historia Regum Britanniae by Geoffrey of Monmouth are found in 15 manuscripts alone in the period covered by the Rhyddiaith Gymraeg 1300-1450 project (Luft et al. 2013) and there are many more. Brut $y$ Brenhinedd belongs to the texts that must have been so relevant for the Welsh readership that they were translated several times. ${ }^{2}$ The same is true for the text called Breuddwyd Pawl, or the Vision of Saint Paul, which will be discussed in this contribution. Having written on the translation found in Oxford, Jesus College MS. 119 (Book of the Anchorite of Llanddewi Brefi) elsewhere, ${ }^{3}$ I present in this article a preliminary approach for comparing it here with another Middle Welsh translation from a very similar Latin source, found in NLW, Llanstephan MS. 4. I argue that such multiple translations allow us important insights into the work of Middle Welsh translators and into the Middle Welsh language itself.

Visio Pauli (VP), known also as the Apocalypse of Paul, is a text written presumably in Greek in Egypt in the mid-third century. ${ }^{4}$ From this,

1. This research is part of the project 'Übersetzungen als Sprachkontaktphänomene - Untersuchungen zu lexikalischen, grammatischen und stilistischen Interferenzen in mittelkymrischen religiösen Texten', led by Prof. Erich Poppe at the Philipps-Universität Marburg, supported by the Fritz Thyssen Foundation. I am thankful to Prof. Erich Poppe for all his help in the preparation of this article. Advice from Dr. Sergey Ivanov was most important for the progress of this study. Needless to say I alone am responsible for the errors in this work.

2. On the relationship between several text witnesses, see Sims-Williams 2016a.

3. Parina 2016; Parina 2017.

4. For a useful introduction to the text in its different version, see Elliott 1999:616-19 and the Hell-on-Line web resource by Eileen Gardiner (http://www.hell-on-line.org/BibJC3.html\#P 
it was translated into Coptic, Syriac, Armenian, Ethiopic, Slavonic (where it is known as Слово о видении апостола Павла/Хождение апостола Павла по мукам) and Latin (in several redactions), from which it was in turn translated into European vernaculars. We are indebted to Caerwyn Williams for his analysis of the Middle Welsh Visio Pauli versions, as is also true of many other religious texts. In his 1962 article he proposed the existence of three independent translations into Middle Welsh, which he mapped onto the Latin tradition using the influential study of Silverstein (1935). One translation belongs to the Latin Redaction I and is found in Shrewsbury School MS. 11 (s. XIV/XV), ${ }^{5}$ NLW MS. Peniarth 32 (Y Llyfr Teg, s. XIV/XV), NLW MS Peniarth 50 (c. 1445), NLW MS. $5267(1438)^{6}$ and NLW MS. Peniarth 267 (1640). ${ }^{7}$ I will not analyse this version in this contribution. My focus is on two translations of Redaction IV, the first found in NLW MS. Llanstephan 4 (s. XIV/XV; hereinafter Llst4) ${ }^{8}$ and the second (hereinafter the LlA version) in several manuscripts, the earliest of which are Oxford, Jesus College MS. 119 (Book of the Anchorite of Llanddewi Brefi, 1346, hereinafter LlA), NLW MS. Peniarth 3 (s. XIII/XIV), NLW MS. Peniarth 14iv (s. XIV1), ${ }^{9}$ NLW MS. Peniarth 15 (s. XIV/XV) and NLW MS. Llanstephan 27 (The Red Book of Talgarth) (s. XIV/XV). ${ }^{10}$

[last accessed 1.05.2017]). See also Hilhorst 2007.

5. The dates for all Welsh manuscripts are taken from Huws (2000:58-64) unless otherwise stated.

6. Williams 1962: 112.

7. Ibid., 113.

8. It should be noted that Llst4 is written by the scribe designated by Daniel Huws as X91, who transcribed NLW MS. Peniarth 32 ( $Y$ Llyfr Teg) as well as parts of Oxford, Jesus College MS. 111 (The Red Book of Hergest), NLW MS. Peniarth 19 and NLW MS. Peniarth 190 (see TEI header for Llst4 in Luft et al. 2013; Huws 2000:60). Llyfr Teg contains a translation of Redaction I of VP (see above), so that one could examine any possible contamination of the two redactions in Llst 4 and Llyfr Teg. This, however, remains a task beyond the scope of this contribution.

9. By Peniarth 14 I refer hereinafter to the fourth part of this composite manuscript (see Huws 2000: 59).

10. Williams believes that the texts in these manuscripts "are all derived from the same original, a Welsh translation of a Latin Redaction IV version of Visio Sancti Pauli, but there is an appreciable measure of variation in their readings, and it is difficult to establish a definite relationship between any of them other than the ultimate derivation from the same original" (Williams 1962:117-8). Poppe (fc.) has demonstrated that these texts show considerable linguistic variation, such as differences in word order, still following Williams's hypothesis of a common ur-translation for the texts in these five manuscripts. 
Finding Latin texts which could be regarded as similar to the supposed source for the Middle Welsh translations is difficult, given the extreme fluidity of the Visio Pauli tradition. When my findings presented elsewhere are summarised, ${ }^{11}$ it emerges that both versions go back to Latin texts of Silverstein's Redaction IV, in the classification of the Jiroušková C-group texts of the so-called Hölle-Fassungen (Jiroušková 2006). The following opinion expressed in a recent study of the text with regard to one particular textual family could, in my opinion, be extrapolated to the whole range of our texts: "The changing internal affiliations of the $\mathrm{B}$ texts in relation to individual variants may be likened to the changing patterns of a kaleidoscope in response to each rotation" (Dwyer 2004:93). Fortunately, these variants have been edited scene by scene from all the available manuscripts ( 48 for the version relevant for us) by Jiroušková (2006), so that I will quote several manuscript witnesses for each case or 'rotation of the kaleidoscope'.

The Latin sources for each of the two different translations of Redaction IV were definitely not identical, which can be shown with the following example:

(1) nini a dywedwn dy uot ti yn vab. y duw byw kan rodeist ti yni orffuys duw sul e hun.

(LlA: 132r $)^{12}$

We say that you are the Son of the living God because you gave us respite on Sunday. ${ }^{13}$

Ni a'th vendig6n di vab du6 kanys ti a rodeist ynni gorffowys bop sul o boeneu ufferna6l.

We bless you, Son of God, because you have given us respite of infernal pains on each Sunday.

In Latin manuscripts we find, amongst others, variants such as the following:

Benedicimus te, fili dei excelsi, qui donasti nobis requiem!

$\left(\mathrm{O}^{5}\right.$; Jiroušková 2006: 847)

Et dicimus te flilium dei vivi, qui dedisti nobis refrigerium diei huius, quod omne

11. See Parina 2017 for further details.

12. The texts are quoted after Luft et al. 2013. I have adapted punctuation and capitalisation. 13. All the translations are mine unless otherwise stated. I translate only the first Welsh quotation unless the differences between the Welsh versions or the Welsh versions and the Latin original are too numerous. 
tempus nostre vite in terra fuit!

(L; Jiroušková 2006: 846)

Benedicimus te, fli dei, qui nobis donasti requiem die dominico tuo!

$\left(\mathrm{P}^{7}\right.$; Jiroušková 2006: 848)

Et nos flium dei credimus, quia dedisti nobis refrigerium huius diei et noctis!

(C6'; Jiroušková 2006: 845)

The LlA version must stem from a Latin text where benedicimus was changed to et dicimus, whereas in the Llst4 version we find a translation of the more common original variant. Other features in the same sentence link the Welsh versions to different Latin manuscript witnesses. Therefore, it is important to understand that we are not dealing with two translations of an identical text, as is often the case in translation studies dedicated to modern literature with a more stable printed source text, but with translations of different sources which must, however, have been similar enough to allow us some comparison. ${ }^{14}$ In this contribution, due to the extreme fluidity of the Latin Visio Pauli, I quote different Latin manuscript witnesses for different instances; for reasons of space, I cannot lay out the reasons for the choices here.

The texts are quite short and additionally Llst 4 lacks a folio, ${ }^{15}$ so that I have excluded the non-matching part of the LlA text from my study. The LlA text thus contains 1258 words; the Llst4 text contains 1213 words. For this study the texts have been aligned with the relevant Latin versions; both texts were also part-of-speech tagged with the help of Dr. Marieke Meelen. ${ }^{16}$ Despite these formal approaches, the size of the texts does not allow us to draw any wider conclusions on the language and style of the texts and my discussion will be by necessity anecdotal.

\section{Comparing two versions}

The following example shows how a comparison of two translations contributes to our understanding of translators' decisions and of the text style.

\footnotetext{
14. Nely van Seventer states that the two translations of Sibilla Tiburtina - the one in the Red Book of Hergest and the White Book of Rhydderch (van Seventer 2018) and the other in Peniarth 14 - are translated from a common source, but independently (van Seventer, 2017).

15. Williams 1962: 124.

16. The PoS tags also contain some morphological information, such as plural number for nouns and adjectives or tense, mood and person-number agreement for verbs. I am indebted to Raphael Sackmann for help in correcting the automatically assigned tags.
} 
(2) Hyeu, medeu vn o'r diefyl, Llyma yr eneit a tremyga6d gorchymynnev duw a'e gyfureithev. Ac yna darllein chartyr a'e pechodeu a'e weithredoed drwc yn yscriuennedic yndi ac yn y varnv yg kyfuyrgoll.

Yea, said one of the devils, here is the soul that despised God's orders and His laws. And then he read/was read a charter with his sins and bad doings written in it and condemning him to perdition.

Edrych6ch, heb 6y, pa wed y tremyga6d yr eneit orchymyn du6 tra vu yn y byt. A'r eneit truan a'e lythyr yn y la6 yn darllein. yn yr h6nn yd oed y bechodeu yn ysgriuen-: edic ac yn y varnu e hun.

(Llst4:36v)

Look, said they, how the soul despised God's orders as it was in the world. And the poor soul reading its letter in its hand, in which its sins were written and condemning itself.

Latin text witnesses differ significantly in this passage. I choose one from Oxford, Merton College, MS. 13 (s. XIV ex. or XV in.), the text published in the 1894 edition of the Welsh LlA text. ${ }^{17}$

Et dixerunt adinvicem: Vidimus, quomodo anima ista contempsit mandata dei in terra! Tunc legit anima ista cartam suam, in qua scripta. erant peccata sua, et se ipsam iudicabat.

(O5; Jiroušková 2006: 790)

In London, British Library, MS. Royal 8.E.XVII (s. XIII ex.-XIV in.), one of the manuscripts that has a text usually closer to the LlA version, the word scripta is absent, but we probably have to suppose that it was there in both sources of the Welsh texts.

Et iterum dixerunt: Ista anima contempsit preceptum domini et legit cartam suam, in qua erant peccata sua, et se ipsam iudicavit.

(L; Jiroušková 2006: 789)

However intensive the variation within the Latin text witnesses is, it is safe

17. For other variants, see Jiroušková 2006: 789-92. 
enough to suppose that the Latin originals had 'a letter', carta, modified by a relative sentence introduced by in qua and containing also the participle scripta.

On the lexical level, the word carta is translated differently in the two versions. In British Latin, $c($ h)arta means mainly a charter, "formal deed or instrument authenticated by witnesses or seal or both", but meanings of "letter or informal note" are also attested (Latham 1997, s.v. charta). The LlA version has chartyr (LlA) (spelled as chartyr in Peniarth 15, sartyr in Peniarth 3 and Peniarth 14, and syartyr in Llanstephan 27). GPC quotes this example under "siartr, siarter, \&c." and suggests that the lexeme is a loanword from M.E. chartre or directly from Old French. The meaning given is "(royal, \&c.) charter; formal document; also fig.", and indeed most of the early examples show its usage in a formal sense; cf. the following:

(3) ef a gennhadawdy brenhin [...] y sartyr ydan y inseil ac inseil y legat.

(Brut y Tywyssogyon, Peniarth 20, 282; Jones 1941:218)

The king sent $[\ldots]$ his charter under his seal and the seal of his legate.

The word is generally rather rare; I have found only eight examples in the Rhyddiaith Gymraeg 1300-1425 corpus for < charter, chartyr, siartyr, sartyr.

Llst4 uses a more generic word for carta - llythyr - a polysemous word, meaning, as the English letter, both 'an alphabetic character' and 'a written text'. In the Rhyddiaith Gymraeg 1300-1425 corpus, 385 examples of (l)lythyr are found. We can thus suggest that chartyr in the LlA version is chosen under the influence of the Latin text, whereas the Llst4 version translator was more target-oriented in his choice.

The participle scripta is translated in both versions as ysgriuennedic. Adjectives in -edic are regarded as one of the strong markers of translation style. ${ }^{18}$ In a prescriptive discussion of the 'natural Welsh language' the form ysgrifennedig as translation from scriptum est is specifically mentioned and criticised. ${ }^{19}$ I will come back to the relationship between Latin perfect participles and -edic adjectives later (3.2.1). In the case of this instance, it is significant that both versions translate scripta as ysgriuennedic, and the data of the prose corpus (Luft et al. 2013) suggest that this lexeme was used quite frequently (55 examples are found for different orthographic variants).

18. See Luft 2016: 172.

19. Morgan 1970:271; on -edic-adjectives, see also Nurmio 2015:174-9, and Russell 1990:7680, 103-8. 
The relative clause containing scripta, on the other hand, is translated with two different constructions. In LIA we find chartyr a'e pechodeu a'e weithredoed drwc yn yscriuennedic yndi, lit. 'a charter with his sins and his bad deeds written it it', with no finite verb and with a conjugated preposition. In Llst4 we find a'e lythyr [...] yn yr h6nn yd oed y bechodeu yn ysgriuenedic, lit. 'and his letter... in this his sins were written' with the relative construction described by Evans as that used "in translated works" (GMW 66) and with a preposition and the demonstrative $y r$ hwnn. ${ }^{20}$ The exact distribution of these relative constructions will be analysed in depth in our project. ${ }^{21}$ What we can say about this example is that the LlA version appears in this instance to be more similar to the style of native texts, whereas Llst4 uses a construction that is much more frequent in translated texts.

\section{Similarities}

I will first discuss two instances in which the two translations show similar behaviour. The first concerns lexical choice. In this preliminary study I can only address one word, but a systemic comparison of the vocabulary of the two versions would be rewarding.

\subsection{Lexical choice}

(4) Ac yna pawl a welas gyr bronn pyrth vffernn deri tanllyt.

And then Paul saw next to the doors of hell fiery trees.

Sefy gGeles pa6l geyr lla6 porth uffern deri tanllyt.

(Llst4:35v)

Vidit Paulus ante portas inferni arbores igneas

In both versions Latin arbores is translated by Welsh deri. According to GPC, it is a plural of dâr which means "oak-tree; fig. foremost warrior, leader, mighty lord" (GPC online, s.v. dâr). However, the translations given in the dictionary do not suit our context. It would be strange to suppose such

20. On this type of relative clause, see also Sims-Williams 2016b:151-2.

21. See footnote 1. 
a detailed knowledge of infernal flora in Welsh and to suggest that the translator deliberately changed a generic word for 'tree' to 'oak'. It is much more likely that we find here, as in the case of the cognate derw (a collective noun), ${ }^{22}$ a generalisation of meaning, ${ }^{23}$ so that an adequate translation of the Welsh versions would be the hyperonym 'trees'. Therefore, the translation by Williams (1892: 635) -“And then Paul saw before the gates of hell a fiery oak-grove"-is to be rejected.

An analysis of other usages of deri in Middle Welsh prose shows that the generalised meaning 'trees' is not unique to the Visio Pauli texts. An example from Brut y Brenhinedd and its translation by John Parry can serve as another illustration:

(5) Ac yno ybu kyfranc kalet yryngthunt. allad llawer o bop tu. canys yno ybrethit y bryttannyeit ogysgot yderi. Ac yno y perys arthur llad y deri.

(Brut y Brenhinedd, BL Cotton Cleopatra MS. B V part i, 78v)

And then there was a fierce battle between them, and many were slain on all sides, for there the Britons were wounded by the shade of the oaks. And then Arthur had the oaks cut down.

(Parry 1937: 158)

Parry translates deri as oaks, but if we look at the Latin text, the general arbores are found there, which is more natural given the context of the episode:

Conserto itaque proelio, stragem Britonibus faciunt, sese uiriliter defendentes. Vsi etenim arborum auxilio, tela Britonum uitabant. Quod Arthurus intuens iussit arbores circa illam partem nemoris incidi.

(HRB IX.145)

Once the battle was joined, they defended themselves valiantly and slaughtered the Britons. Moreover the trees permitted them to avoid the Britons' weapons. Noting this, Arthur ordered the trees surrounding that part of the forest to be cut down.

(HRB: 196)

22. GPC, s.v. derw-“oaks, oak-trees; (sometimes) terebinth tree (in bibl.); trees; plants having some resemblance to oak; transf. (in medieval poetry) oak coffin; fig. valiant man, stout warrior; of oak, oaken".

23. See Geeraerts 1997: 68-79. 
I take this example as proof of the second part of John Rhŷs' note in his preface to the Book of the Anchorite edition:

The texts, being translations, cannot be regarded as the best models for Welsh prose, but they are important in the lexicographical sense, as helping to fix the exact meaning and connotation of words, the indefiniteness of which, when they occur in medieval Welsh poetry, leaves not a little room for doubt.

(Morris-Jones and Rhŷs 1894:v)

While the critical examination of the first statement on the syntactical qualities of the translated texts is the core of our project, the second statement on the importance of translated texts for semantic research remains true - so that despite the existing precision of lexicographical description of Middle Welsh in GPC, these texts can still yield more information.

\subsection{Grammar}

Another aspect where one can find similarity is grammar. I will first address some more general issues and then turn to the question of the tense marking of the verb gwelet 'see'.

Since we are dealing with two translations, one would expect to find features of the translational style, such as those noticed by Roberts: ${ }^{24}$ greater use of concord of a plural adjective and noun; concord of a plural verb with a plural subject following; the position of the adjective before the noun it modifies; the use of demonstrative pronouns as relatives. I have discussed an example of the last feature in section 1, and ex. 18 is another case of this. Concord of a plural subject and verb is discussed for one sentence in ex. 20 . There are no more data in our sample for further comparison. The following can be said about the syntactic behaviour of adjectives: there are no plural adjectives in attributive positions, but this evidence is neutral because the adjectives found with plural nouns do not have plural forms (e.g. deri tanllyt 'fiery trees' and $y$ weithredoed da 'his good deeds' in both versions). As for the position of the adjective, in LlA adjectives precede the noun twice in 17 noun phrases with adjective in attributive function; in Llst4 this occurs in 3 out of 21 cases. These results are comparable, though not every individual noun phrase has an equivalent in the other version. Altogether there are five examples of adjectives preceding nouns in LlA and Llst4, and among these, there are three examples of phrases with ordinal numerals which always precede the noun (GMW 48): yn y pedweryd nef 'in the fourth heaven' (LlA);

24. Roberts 1975: xxviii, quoted in Luft 2016: 172 and Nurmio 2016:162, Russell 2017: 231. 
hyt $y$ trydyd nef 'up to the third heaven'; o'r nawuet awr 'from the ninth hour' (Llst4). In both versions we also find examples of the adjective preceding the noun when the nominal phrase is used in a vocative function: wynnvydedic pawl ebostol 'o blessed Paul apostle' (LlA) and druanaf eneit 'poorest soul' (Llst4). A detailed analysis of the frequency of this feature in native texts and the texts of LIA is to be undertaken within our project; what can be demonstrated at the moment is the presence of some examples of adjectives preceding nouns (in the future ordinal numerals should be excluded from the statistics since they always precede the noun in M.W.), but the very limited number of these examples is also clear.

The usage of the verb gwelet in the past is the second aspect in which we can see similarity in the grammar of our versions that is not just due to the fact that both are written in Middle Welsh but that is possibly due to the fact that they are both translations. Visio Pauli is, as the title suggests, a text focused on vision, so that Latin vidit is used in the text frequently enough to allow generalisations on how the Latin perfect of a perception verb is translated.

In the corresponding parts of VP in LlA and Llst4 we find vidit six times. It is translated twice in both versions with the imperfect form gwelei:

(6) Ac edrych a oruc pawl o bell y vrthaw, ac ef a welei eneit pechadur yn ruym gann seith gythreul wedy'r dwyn yr awr honno o'r corff, ac ynteu yn gweidi ac yn vdaw.

(LlA: 131r)

And Paul looked afar off, and he could see a sinner's soul bound by seven devils newly taken, at that hour, from the body, while he shrieked and howled

(Williams 1892: 636)

Ac edrych a oruc Pawl y'r nef ac y'r daear, ac ef a welei eneit pechadur y.r6ng seith kythreul yn vda6 ac yn dryc.yruerth gGedy y dGyn y dyd h6nn6 o'r korff.

(Llst4:36r)

Post hoc asspexit longius, vidit animam peccatricem inter septem diabolos ululantem et exeuntem de corpore eo die.

(L'; Jiroušková 2006: 784)

Three times vidit is translated by the preterite form gwelas (in LlA)/gweles (in Llst4); see ex. 4 above or the following sentence. 
(7) Ac yna y gwelas pawl y nef yn kyffroi.

(LlA: 131v)

And there Paul saw the heavens stirred.

(Williams 1892: 637)

ac yna y gGeles pawl y nef yn kyffroi.

(Llst4: 37r)

Et tunc Paulus vidit celum subito moveri.

However, if we look at other text witnesses of the LlA translation, we can see variation there: Ac yna y gwelei Bawl y nef yn kyfroi (Peniarth 3: 29); ac yna y gwelei pawl y nef yn kyffroi (Llanstephan 27:54r); Ac yna y gweles y nef yn kyffroi (Peniarth 14:159).

On one occasion on which the versions differ, LlA has a preterite form, while Llst4 has an imperfect.

(8) Odyna y gwelas pawl gwyr a graged yn noethon.

(LlA: 130v)

Then Paul saw men and women naked.

(Williams 1892: 636)

ac ef a welei yn y pyde6 gGyr a graged meibyon a merchet yn noethon.

(Llst4: 36r)

Et vidit Paulus in alio loco viros et mulieres nudos.

(L; Jiroušková 2006: 778)

This variation seems to be indicative of a very fine semantic distinction between gwelei/gwelas forms. The significance of this imperfect/preterite variation becomes clear in comparison to the language of native prose. One usually encounters the following example of gwelei during the first days of learning Middle Welsh:

(9) Ac ef a welei lannerch yn $y$ coet, o uaes guastat.

(Pwyll Pendeuic Dyuet, Thomson 1957:1.13) 
And he could see a clearing in the forest, a level field.

(Davies 2007:3)

D. Simon Evans lists a separate meaning "possibility" for the imperfect with verbs of perception (GMW 110), which we also see in the translation of Davies. However, without analysing the semantics of gwelei in a strict formal way, we can say that there are also numerous examples in which it is appropriately translated with the English past simple form saw. ${ }^{25}$ The preterite of gweled is also used in native prose, in subordinate clauses and more rarely in main clauses; see

(10) Porth y gaer a welas yn agoret; ny bu argel arnei.

(Manawydan uab Llyr, Hughes 2007:6.180)

She saw the gate of the fort open; there was no concealment on it. ${ }^{26}$

Therefore, we may suggest the existence of a fine semantic distinction between gwelei and gwelas in the native prose, with the preference for gwelei. The data of the Rhyddiaith Gymraeg 1300-1425 corpus (Luft et al. 2013) show the following distribution:

\begin{tabular}{|c|c|c|c|c|c|}
\hline & total & LlA & LlA\% & Peniarth 4 & $\begin{array}{c}\text { Peniarth } \\
4 \%\end{array}$ \\
\hline $\begin{array}{l}(g) \text { welas }+(g) \\
\text { weles }\end{array}$ & 1476 & 20 & 57,1 & 40 & 23,4 \\
\hline (g)welei & 997 & 15 & 42,9 & 131 & 76,6 \\
\hline
\end{tabular}

We intend to investigate this phenomenon in detail in the course of our project, but we can make the preliminary deduction from these data that gwelei is significantly more frequent in the part of the White Book of Rhydderch containing the Four Branches, Culhwch ac Olwen and the so-called three romances than it is in L1A. The language of LlA shows another distribution, preterite forms being more frequent. The hypothesis is that translators were influenced by Latin which did not have such a fine distinction between the meanings as gwelei vs. gwelas. The use of the two forms in both independent

25. Cf. Kyrchu i llys a oruc ynteu; ac yn y llys ef a welei hundyeu ac yneuadau (Pwyll Pendenic Dyuet, Thomson 1957: 1.75) "He made his way to the court. He saw sleeping quarters there and halls" (Davies 2007: 5).

26. "She found the gate of the fort open - it was ajar" (Davies 2007: 40). 
translations suggests that both were used actively, but the variation between the translations as in ex. 8, as well as the variation between text witnesses of one version (in ex. 7), seems to indicate that usage was more fluid.

\section{Differences}

In this section I will look at differences between the versions, again first in the domain of lexical choice and then in grammar.

\subsection{Lexical choice}

The small scale of this study, as already mentioned, does not allow for any large-scale generalisations. In the following three examples, two different words are used in Welsh translations as equivalents of a Latin word - their occurrence in the same context shows that they are synonyms, and these Latin contexts can provide information on their exact meaning.

Latin ovile is translated by phald in LlA and keil in Llst4.

(11) Et erant anime in illo loco una super aliam quasi oves in ovili.

(L7; Jiroušková 2006: 778)

A hynny pob vn ar warthafy gilyd. megys deueit y mywn phalt.

And those [souls] one above another as sheep in sheepfold.

ar eneideu pob vn ar benn y gilyd megys deueit y my6n keil.

Welsh ffald is a loanword from O.E. fald (as in Modern English sheepfold) and is used frequently in Middle Welsh prose inter alia in legal contexts which allow us to understand its meaning easily. In the following example the payments for burning a certain type of building are discussed:

(12) Buarth, a thalgell, a chreu moch, a ffalt deueit, dec ar hugeint a tal pob vn.

(Llyfr Blegywryd; Williams \& Powell 1961:96)

A cattle yard, a lean-to, a pig-sty, and a sheep fold are each thirty pence in value.

(Richards 1954: 93) 
The word keil is used not only in Llst4 but also in two text witnesses of the LlA version: megis deueit y mewn keil (Pen3, Pen14). I was only able to find one more attestation of this word in the prose corpus:

(13) Kyrchwn heb ohir yr haner gwyr rackw a dilewn wynt val deveit y mewn keil wynt ${ }^{27}$ a rannwn wynt ar hyt y kyvoeth.

(Brut y Brenhinedd; NLW Peniarth 21:5r)

Let us attack without delay those half-men and destroy them as sheep in a sheepfold and divide them throughout the realm.

Compared to the standard edition of Historia Regum, the following translation seems to be very free:

Armate uos, uiri, armate et per densatas turmas incedite. Nulla mora erit quin semimares istos uelut oues capiemus atque captos per regna nostra mancapabimus.

(HRB I.20)

To arms, men, to arms, close your ranks and advance. We shall soon capture these effeminates as if they were sheep, and make them slaves in our country.

(HRB: 24)

However, if we look at the variants of HRB, we will find in the so-called first variant version a construction closer to what we find in Welsh:

Armate vos, o viri, armate celeriter et per turmas ordinatas ad pugnam incedite. Nulla mora erit quin semimares istos velut oves intra caulas capiemus et captos captivos per regna nostra mancipabimus.

(Hammer 1951:37, see also HRB:14)

It could be significant that here we find a Latin word caulas phonetically close to the Welsh one, which is also noted as one of the etymological hypotheses for the word in GPC (s.v. cail): "i'w gysylltu o bosibl â'r ail elf. yn bugail a bod cail< Clt. *kolia o'r gwr. * qel- 'gyrru', ond cf. Llad. caule 'corlan"”-'to be possibly related to the second element in bugail, cail < Celtic *kolia from the root * qel- 'to drive', but cf. Lat. caule 'fold".

Apart from these four instances in the Rhyddiaith Gymraeg 1300-1425 corpus, the word is attested in the following passage:

27. The second wynt is probably superfluous. 
(14) Ena keuyt e giudaut en erbyn y gilid yg capadocia ac en oes h6nn6 e keytheir pampilia cany doeth trwy e drws yr keil.

(Proffwydoliaeth Sibli Ddoeth; Isaac et al. 2013; Peniarth 14:51)

Then its citizens will rise against each other in Cappadocia, and at that time Pamphilia will be captured since they did not come through the gate of the fold. ${ }^{28}$

There are also some examples in poetry; see

(15) Pe bawn, myn y Pab annwyl, / Yn y llwyn, anneall hwyl, / Cyd y bu'r gwr, cyflwr cail, / Ebwch gwae, wrth y baich gwiail, / Gwyn ac addwyn ei hwyneb, I -Gwae fi!-ni welwn i neb.

(Dafydd ap Gwilym, 146:1.29; Disgwyl yn Ofer)

If I were in the woods, / in the dear Pope's name, senseless condition, / as long as the man with the load of sticks, / state of imprisonment, exclamation of grief, / pure and tender is her face, / - woe is me!-I wouldn't see anyone.

(http://www.dafyddapgwilym.net/)

But in this example cyflwr cail is rephrased with the Modern Welsh mewn cyflwr o gaethiwed 'state of distress/imprisonment' and cannot give us a clear indication of the lexeme's meaning. Therefore, the VP examples show us the importance of translational texts as sources of information on the semantics of less frequent words; this information is provided both by comparison to the translations' originals and, in the case of multiple translations, by equivalents from other versions.

I will briefly address another point at which our translators differ in their lexical choice. Here is the list of seven plagues around a fiery furnace:

(16) Ac yng kylch y ffwrnn yd oedynt seith pla. kynntaf oed eiry. Ar eil oed tan. Ar tryded oed ia. Pedwared oed waet. Pymhet oed seirff. Chwechet oed mellt. Seithuet oed derewant.

(LlA: 129r)

28. Nely van Seventer kindly supplied me with the part of her research concerning this passage. The corresponding Latin text is Tunc surget gens adversus gentem in Cappadociam et Pamphiliam captivabunt in ipsius tempore, eo, quod non introerit per ostium in ovile (Sackur 1898: 182-3) 'Then people will rise against people in Cappadocia, and they will capture Pamphilia in that age, for this reason: because they did not enter through the door into the fold' (translation by N. van Seventer). In another translation found in the White Book of Rhydderch ovile is translated by dauatty, literally 'sheep-house': Ac yna y kyuyt kenedyl yn y teyrnas a elwir Capadocia, atheyrnas Pampilia a geithiwant yn amser hwnnw am nat yntredant drwy drus y dauatty (NLW Peniarth 5, 13r). 
Around this furnace were seven plagues: the first was snow, the second was fire, the third was ice, the fourth was blood, the fifth was snakes, the sixth was lightning, the seventh was stink.

TrGy y seith fflam hynny y dyellir y seith poen yssyd yn uffern; nyt amgen eiry, ia, tan, gGres, nadred, tywylloc[h], drewyant.

(Llst4:35v)

Et VI plage sunt in circuitu fornacis: Prima est nix, secunda glacies, tercia sanguis, quarta ignis, quinta serpentes, sexta fetor.

(C'; Jiroušková 2006: 671)

In LlA the translator uses seirff (sg. sarff, a borrowing from spoken Latin * sarpans < Lat. serpens; GPC s.v. sarff) and in Llst4 nadred (a word of Celtic origin) for serpentes. ${ }^{29}$ A search through the word lists of the Rhyddiaith Gymraeg 1300-1425 corpus shows that both words for snakes are quite frequent words; different forms of neidr occur 133 times, and different forms of sarff are found 219 times. I do not think, however, that the difference in usage in the two versions is indicative of anything more than the closeness of the meaning of these words. Another argument for this is the use of a doublet in Llst4 where LlA has only nadred:

(17) Odyna y gwelas pawl gwyr a graged yn noethon a phryfet. a nadred yn y bwyta.

Then Paul saw men and women naked, and worms and adders devouring them.

(Williams 1892: 636)

ac ef a welei yn y pyde6 gGyr a gGraged meibyon a merchet yn noethon, a phryfet a seirff a nadred yn eu knoi.

(Llst4:36r)

Et vidit Paulus in alio loco viros et mulieres nudos et vermes et serpentes comedentes eos.

(L7; Jiroušková 2006: 778)

29. Interestingly something similar happens with the translations of Latin plage in the same sentence: LlA has pla, while Llst4 uses poen 'pain'. 


\subsection{Differences: syntax}

I now turn to some instances of differences in syntax.

\subsubsection{Translation of Latin perfect participles}

An example of a Latin perfect participle scriptum translated by ysgriuennedic in both versions has already been shown above (ex. 1). There is another example in this text in which the translations differ.

(18) Ac yna dangos pydew a oruc idaw. a seith ynseil arnaw.

And then he showed him a pit and seven seals upon it.

[lost folio] yn pyde6 inseiledic o seith inseil.

(Llst4: 36r)

Tunc ostendit ei puteum signatum septem sigillis.

(O5; Jiroušková 2006: 766)

Although the Llst4 text is incomplete here, the nominal phrase is preserved. While the LlA version uses a prepositional construction and omits the translation of signatum 'sealed', the Llst4 version uses a construction very close to that of Latin, with inseiledic 'sealed' following the noun it modifies and turning the Latin instrumental ablative of septem sigillis into a prepositional phrase governed by the preposition $o$, here in the sense "by, by means of" (GMW 204).

\subsubsection{Relative clauses}

The number of different ways to construct a relative sentence in Middle Welsh accounts for the differences in the versions in this respect. In ex. 1, one such instance was shown; I will now discuss two other differences.

(19) y rei hynny heb yr angel ny credassant ygrist y gwr a diodefawt anghev yr pobyl y byt.

Y rei heb.y Mihangel. ny chredassant y vab du6 yr h6nn a diodefa6d yr y byt.

Hii, qui non crediderunt in filium dei, qui passus pro salute mundi.

( $\mathrm{M}^{4}$; Jiroušková 2006: 773) 
In the LlA version we find a construction using y gwr 'the man' as an antecedent (see GMW 69). This is a construction similar to that used in poetry to refer to God in Juvencus $9^{30}$ or in Kyntaw geir a dywedaw (y gur am creuys e am nerth 'the one who created me is my strength'). ${ }^{31}$ The Llst4 version uses the construction with the demonstrative pronoun yr hwnn, mentioned already in section 1. Here again, we can place Llst4 closer to the translated end of the 'native vs. translated' scale than the LlA version.

The importance of weighting all the features against each other with regard to their significance and the need for a more systematic study emerges from the next example. Here is the first sentence of our texts:

(20) Dyw sul dyd detholedic yw, yn yr hwnn y caffant yn y dyd hwnnw yr eneideu a uont yn y poenev, orffwys yn diboen trwy lewenyd.

Sunday is a chosen day, whereon the souls that are in pains receive rest without pain through joy.

(Williams 1892: 635)

Pwy bynnac a vynno gGybot p6y gyntaf a lauurya6d y beri gorffowys du6 sul y'r eneityeu a vei yn uffern.

(Llst4:35v)

Whoever would like to know who was the first to bring about peace on Sunday to the souls that were in hell.

The exact wording of the Latin source for both versions is not easily established. ${ }^{32}$ What is important here is that both versions end with a fragment which can be translated as 'souls that were in (pains/hell)'. According to normative expectations, the form of the verb bod should not agree in number with the plural antecedent; however, as shown in Plein (2016:197), even in the Mabinogion sub-corpus, 23\% of examples of bod in relative clauses following a plural nominal antecedent show agreement, and shorter non-Mabinogion texts show such behaviour in 54\% of cases. Here again, we find a feature which is related to the 'native vs. translated' scale, but the presence of concord is not a strong indication of the translational style,

30. See Falileyev 2016: 25.

31. See Falileyev 2012: 54, 230.

32. For the variants; see Jiroušková 2006: 654-659. 
since almost a quarter of Mabinogion examples also show it. But it is nevertheless interesting that we find a variant in the LlA version that is closer to the translation style than the one used in Llst4.

\section{Conclusions}

Studying various translations of one text-even given the extreme fluidity both of the source and of the target texts - is rewarding and delivers important results. First, as noticed already by Rhŷs in 1894, these texts are sources of valuable semantic information, since we can relate Middle Welsh lexemes to their equivalents found in other versions as well as to those in the Latin original.

Secondly, as we have seen, several features have been identified in Welsh philology as marks of translation and therefore often as indicators of 'unnatural' translation style. By comparing our two Visio Pauli versions, we can see that some of these features are not found in our translated texts (adjective congruence with plural nouns-possibly due to the sample size), some appear occasionally (adjectives preceding nouns) but are equally rare in both versions, while some are present only in one version (relative clause with demonstrative). Our sample size does not allow us to make statistically valid statements on the frequency of these features. However, I hope to have demonstrated that the systematical study of such features can help us to draw a map of the language of Middle Welsh prose, seeing it not in a binary opposition of native vs. translated texts but as a continuum using these features as some kind of coordinates. While a quantitative comparison of the aforementioned syntactic features within the language of native texts has not been conducted for this contribution, it seems that the LlA version would be somewhat closer to the standard native texts on this continuum than the Llst4 version. Thus, a comparison of multiple translations helps to understand better the syntax and lexis of Middle Welsh as well as the personal choices of individual translators.

Philipps-Universität Marburg/ Institute of Linguistics, RAS, Moscow 


\title{
Appendix I. List of Latin manuscripts mentioned in text
}

\author{
C $\quad$ Cambridge, St John’s College, MS. D.20 (95) (s. XV) \\ L $^{7} \quad$ London, British Library, MS. Royal 8.E.XVII (s. XIII ex.-XIV in.) \\ L $^{8} \quad$ London, British Library, MS. Royal 8.F.VI (s. XV) \\ $\mathbf{M}^{4} \quad$ München, Bayerische Staatsbibliothek, clm 12728 (s. XV) \\ $\mathrm{O}^{5} \quad$ Oxford, Merton College, MS. 13 (s. XIV ex. or XV in.) \\ $\mathbf{P}^{7} \quad$ Paris, Bibliothèque Nationale, Ms. lat. 3529A (s. XIV in.)
}

\begin{abstract}
Abbreviations
GMW

Evans, D.S., 1964, A Grammar of Middle Welsh, Mediaeval and Modern Welsh Series. Supplementary volume. Dublin.

GPC Online. University of Wales Centre for Advanced Welsh \&

GPC Celtic Studies, 2014. http://geiriadur.ac.uk/gpc/gpc.html [accessed 1.05.2017].

Reeve, M. D., ed., 2007, Geoffrey of Monmouth. The History of the

HRB Kings of Britain, translated by Neil Wright, Arthurian Studies 69, Woodbridge.
\end{abstract}

\section{References}

Dafydd ap Gwilym - http://www.dafyddapgwilym.net [accessed 1.05.2017]. Davies, S., 2007, The Mabinogion, Oxford/New York.

Dwyer, M.E., 2004, Contributions to the Textual History of the Medieval Latin Redactions of the Visio Pauli, Ph.D. thesis, University of Tasmania.

Elliott, J.K., 1999, The Apocryphal New Testament: a Collection of Apocryphal Christian Literature in an English Translation, Oxford.

Falileyev, A., 2016, Llawlyfr Hen Gymraeg, Aberystwyth.

Falileyev, A., 2012, Из ранней валлийской поэзии [From early Welsh poetry], Sait-Petersburg.

Geeraerts, D., 1997, Diachronic Prototype Semantics: a Contribution to Historical Lexicology, Oxford/New York. 
Hammer, J., 1951, Geoffrey of Monmouth. Historia regum Britanniae. A Variant Version Edited from Manuscripts, Cambridge, MA.

Hilhorst, A., 2007, 'The Apocalypse of Paul: Previous History and Afterlife', in: Bremmer, J.N., Czachesz, I., eds., The Visio Pauli and the Gnostic Apocalypse of Paul, Studies on early Christian apocrypha, Leuven, [Dudley, MA], 1-22. Hughes, I., 2007, Manawydan uab Llyr: Trydedd gainc y Mabinogi; golygiad newydd ynghyd â nodiadau testunol a geirfa lawn, Cardiff (2nd ed.).

Huws, D., 2000, Medieval Welsh Manuscripts, Cardiff.

Isaac, G.R., Kapphahn, K., Nurmio, S., Rodway, S., \& Sims-Williams, P., 2013, Rhyddiaith Gymraeg o Lawysgrifau'r 13eg Ganrifl13th Century Welsh Prose Manuscripts, Aberystwyth, http://cadair.aber.ac.uk/dspace/handle/2160/11163 [accessed 1.05.2017].

Jiroušková, L., 2006, Die Visio Pauli. Wege und Wandlungen einer orientalischen Apokryphe im lateinischen Mittelalter unter Einschluss der alttschechischen und deutschsprachigen Textzengen, Mittellateinische Studien und Texte 34, Leiden. Jones, Th., 1941, Brut y tywysogyon: Peniarth Ms. 20, Cardiff.

Latham, R.E., \& Howlett, D.R., 1997, Dictionary of Medieval Latin from British Sources: $A-L$, London.

Luft, D., Thomas, P.W., \& Smith, D.M., 2013, Rhyddiaith Gymraeg 1300_ 1425. http://www.rhyddiaithganoloesol.caerdydd.ac.uk [accessed 1.05.2017]. Luft, D., 2016, 'Tracking ôl cyfieithu: Medieval Welsh Translation in Criticism and Scholarship', Translation Studies 9.2, 168-82.

Morgan, T.J., 1970, 'Cymraeg Naturiol Cywir' [Correct natural Welsh], Ysgrifau Beirniadol 13, 254-75.

Morris-Jones, J., \& Rhŷs, J., 1894, The Elucidarium and Other Tracts: in Welsh from Llyvyr agkyr Llandewivrevi A.D. 1346 (Jesus College, MS. 119), Oxford. Nurmio, S., 2015, Studies in Grammatical Number in Old and Middle Welsh, unpublished $\mathrm{PhD}$ thesis, University of Cambridge.

Parina, E., 2017, 'A Welsh Version of Visio Pauli: its Latin Source and the Translator's Contribution', Apocrypha 28, 155-86.

Parina, E., 2016, 'Об одном средневаллийском переводе Visio Sancti Pauli' [On one Middle Welsh translation of the Visio Sancti Pauli], Indo-European Linguistics and Classical Philology 20, 842-50.

Parry, J.J., 1937, Brut y Brenhinedd. Cotton Cleopatra version, Cambridge, MA. Plein, K., 2016, Verbalkongruenz im Mittelkymrischen, unpublished PhD thesis, University of Marburg.

Poppe, E., fc., Syntactic Variation in Middle Welsh: New Perspectives, in: Proceedings of the First European Symposium in Celtic Studies.

Richards, M., 1954, The Laws of Hywell Dda: the Book of Blegywryd, Liverpool. Roberts, B.F., ed., 1975, Cyfranc Lludd a Llefelys, Dublin. 
Russell, P., 2017, “Go and Look in the Latin Books': Latin and the Vernacular in Medieval Wales', Proceedings of the British Academy 206, 213-46.

Russell, P., 1990, Celtic Word-formation: the Velar Suffixes, Dublin.

Sackur, E., 1898, Sibyllinische Texte und Forschungen. Pseudometodius, Adso und die Tiburtinische Sibille, Halle.

Silverstein, Th., 1935, Visio Sancti Pauli. The History of the Apocalypse in Latin together with Nine Texts, London.

Sims-Williams, P., 2016a, 'The Welsh Versions of Geoffrey of Monmouth's 'History of the Kings of Britain', in: Harlos, A., \& Harlos, N., eds., Adapting Texts and Styles in a Celtic Context. Interdisciplinary Perspectives on Processes of Literary Transfer. Studies in Honour of Erich Poppe, Münster, 53-74.

Sims-Williams, P., 2016 b, 'John Morris-Jones and his Welsh Grammar', Transactions of the Honourable Society of Cymmrodorion 22, 134-53.

Thomson, R.L., 1957, Pwyll Pendeuic Dyuet, Mediaeval and Modern Welsh Series 1, Dublin.

van Seventer, N., 2018, 'The Translation of the Sibylla Tiburtina into Middle Welsh', in: Jones, A. Ll., \& Fomin, M., eds., 'Y Geissaw Chwedleu'. Proceedings of the $7^{\text {th }}$ International Colloquium of Societas Celto-Slavica, Studia CeltoSlavica 8, Bangor, 109-118.

van Seventer, N., 2017, 'The Middle Welsh Sibylla Tiburtina: One Text, Two Translations', paper delivered at the XI Cardiff Conference on the Theory and Practice of Translation in the Middle Ages (Vienna).

Williams, J.E. Caerwyn, 1962, 'Welsh Versions of Visio Sancti Pauli', Études Celtiques 10, 109-26.

Williams, R., 1892, Selections from the Hengwrt Mss. Preserved in the Peniarth Library: Vol. II, London.

Williams, St.J., Powell, J. E., 1961, Cyfreithiau Hywel Dda yn ôl Llyfr Blegywryd, Cardiff. 